\title{
Fertilization regimes affect the soil biological characteristics of a sudangrass and ryegrass rotation system
}

\author{
LI WenXi ${ }^{1}$, LU JianWei ${ }^{1 *}$, LI FangBai ${ }^{2}$, WANG Yan ${ }^{2}$, LU JunMing ${ }^{3} \&$ LI XiaoKun ${ }^{1}$ \\ ${ }^{1}$ College of Resources and Environment, Huazhong Agricultural University, Wuhan 430070, China; \\ ${ }^{2}$ Guangdong Institution of Eco-environment and Soil Science, Guangzhou 510650, China; \\ ${ }^{3}$ Agricultural Research Institution, Datonghu Administration District of Jingzhou City, Jingzhou 433221, China
}

Received March 28, 2010; accepted February 28, 2011

\begin{abstract}
The sudangrass (Sorghum sudanense) and ryegrass (Lolium multiflorum L.) rotation is an intensive and new cropping system in Central China. Nutrient management practices in this rotation system may influence soil fertility, the important aspects of which are soil biological properties and quality. As sensitive soil biological properties and quality indicators, soil microbial community activity, microbial biomass, enzyme activities, soil organic matter (SOM) and total N resulting from different fertilization regimes in this rotation system were studied through a four-year field experiment from April 2005 to May 2009. Treatments included control (CK), fertilizer phosphorus and potassium (PK), fertilizer nitrogen and potassium (NK), fertilizer nitrogen and phosphorus (NP) and a fertilizer nitrogen, phosphorus and potassium combination (NPK). Soil microbial community activities in the NK, NP and NPK treatments were significantly lower than those in the CK and PK treatments after the sudangrass and ryegrass trial. The highest microbial biomass $\mathrm{C}$, microbial biomass $\mathrm{N}, \mathrm{SOM}$, total N, sucrase and urease activities were found in the NPK treatment, and these soil quality indicators were significantly higher in the NK, NP and NPK treatments than in the PK and CK treatments. Soil microbial biomass and enzyme activities were positively associated with $\mathrm{SOM}$ in the sudangrass and ryegrass rotation system, indicating that fertilization regimes, especially $\mathrm{N}$ application, reduced microbial community activity in the soil. Proper fertilization regimes will increase microbial biomass, enzyme activity and SOM and improve soil fertility.
\end{abstract}

microbial activity, microbial biomass carbon and nitrogen, enzyme, fertilization regimes

Citation: $\quad \mathrm{Li} \mathrm{W} \mathrm{X,} \mathrm{Lu} \mathrm{J} \mathrm{W,} \mathrm{Li} \mathrm{F} \mathrm{B,} \mathrm{et} \mathrm{al.} \mathrm{Fertilization} \mathrm{regimes} \mathrm{affect} \mathrm{the} \mathrm{soil} \mathrm{biological} \mathrm{characteristics} \mathrm{of} \mathrm{a} \mathrm{sudangrass} \mathrm{and} \mathrm{ryegrass} \mathrm{rotation} \mathrm{system.} \mathrm{Sci} \mathrm{China}$ Life Sci, 2011, 54: 572-579, doi: 10.1007/s11427-011-4175-9

With increasing population, intensive cultivation is necessary to produce more food from limited farmland [1,2]. One particularly serious problem is the decrease in organic matter content of agricultural soils, which may endanger soil fertility [3]. Fertilizers have been widely recommended for sustainable agricultural production in the world, including China [2,3]. Because of fertilizer application and crop growth, the structure of agroecosystems is also altered [4,5].

Fertile soils provide essential nutrients for crop growth and have good soil structure [6]. Microbial community ac-

*Corresponding author (email: lujianwei@ mail.hzau.edu.cn) tivity, microbial biomass and enzymes are all soil quality indicators in agroecosystems [7]. Microbial community activity is an important indicator of microbial function in the soil and can easily be affected by anthropogenic disturbances such as fertilization regimes [8]. Fertilizers, especially nitrogen $(\mathrm{N})$, phosphorus $(\mathrm{P})$, and potassium $(\mathrm{K})$ may directly or indirectly induce changes in soil biological characteristics [9]. Katayama et al. [4] have reported that fertilizer application has a direct effect on the composition of the soil microbial community in monocultures and fallow soil. Some evidence also suggests that soil microbial community activity is indirectly affected by changes in plant commu- 
nity composition resulting from fertilizer regimes [10,11]. Microbial biomass also has a critical role in the soil, regulating processes such as organic matter decomposition and nutrient cycling [12]. Enzyme activities are associated with the microbial biomass [13,14]. Enzymes have a crucial role in the cycling of nutrients such as carbon (C) and $\mathrm{N}$, and fertilization regimes can also increase soil enzymatic activities in agricultural systems [15]. Organic matter and total N are important chemical quality indicators in the soil. Fertilization regimes directly or indirectly influence soil organic matter (SOM) and total $\mathrm{N}[16,17]$.

Sudangrass (Sorghum sudanense, a $\mathrm{C}_{4}$ species) and ryegrass (Lolium multiflorum L., a $\mathrm{C}_{3}$ species) are graminaceous forage grasses which are important for livestock farming and fisheries in China. In recent years, because of the rapid development of forage grasses with the sufficient light and abundant rainfall in the south of China, the sudangrass and ryegrass rotation system has developed as a new type of cropping system [18]. In this rotation, forage grasses are harvested eight or nine times every year, and because of its higher frequency and intensity, nutrient uptake induced by the greater amounts of aboveground biomass is much higher than that of common farm crops $[18,19]$. As an intensive and new cropping system, it is essential to develop proper nutrient management measures for crop growth requirement using fertilization regimes that are sustainable and healthy for agroecosystems. The objectives of this research were (i) to study the effect of fertilization regimes on microbial characteristics such as community activity, microbial biomass $\mathrm{C}(\mathrm{MBC})$ and microbial biomass $\mathrm{N}(\mathrm{MBN})$, enzyme activities, SOM and total $\mathrm{N}$ in soil, and (ii) to investigate proper fertilization measures for sustainable soil fertility and agricultural production for the increasing population.

\section{Materials and methods}

\subsection{Description of the study site}

The field experiment was carried out on the Agricultural Research Station of Datonghu Administration District, Jingzhou, Hubei Province, China $\left(30^{\circ} 3^{\prime} \mathrm{N}, 113^{\circ} 45^{\prime} \mathrm{E}\right)$. The experimental soil is classified as a fluvo-aquic soil with a soil $\mathrm{pH}$ of 6.93 (1:2.5 water: soil), $18.5 \mathrm{~g}$ organic matter $\mathrm{kg}^{-1}, 1.05 \mathrm{~g}$ total $\mathrm{N} \mathrm{kg}^{-1}, 12.0 \mathrm{mg}$ available $\mathrm{P} \mathrm{kg}^{-1}$, and $121.7 \mathrm{mg}$ available $\mathrm{K} \mathrm{kg}^{-1}$. The climate is warm and moist, and the average annual precipitation is around $1200 \mathrm{~mm}$.

\subsection{Experimental materials and design}

The four-year rotation experiment incorporating planting sudangrass (Sorghum sudanense cv. Yanchi) in summer and ryegrass (Lolium multiflorum cv. Abundant) in winter was conducted in Jianghan Plain from April 2005 to May 2009.
Sudangrass and ryegrass seeds were directly broadcast sown in each plot $(7.5 \mathrm{~m} \times 2 \mathrm{~m})$, and the two forage grasses were harvested eight times a year.

The experimental design consisted of five treatments in a randomized block design with four replicates, including control (CK), fertilizer phosphorus and potassium (PK), fertilizer nitrogen and potassium $(\mathrm{NK})$, fertilizer nitrogen and phosphorus (NP) and a fertilizer nitrogen, phosphorus and potassium combination (NPK). Based on our previous research $[18,19], \mathrm{N}, \mathrm{P}$, and $\mathrm{K}$ were applied at rates of $450 \mathrm{~kg} \mathrm{~N} \mathrm{hm}^{-2}, 180 \mathrm{~kg} \mathrm{P}_{2} \mathrm{O}_{5} \mathrm{hm}^{-2}$ and $300 \mathrm{~kg} \mathrm{~K}_{2} \mathrm{O} \mathrm{hm}^{-2}$ in the sudangrass trial, with one third of the $\mathrm{N}$ and half of the $\mathrm{K}$ applied as a basal dressing and the remaining nutrients applied in three applications by topdressing. In the ryegrass trial, total nutrient application rates were $225 \mathrm{~kg} \mathrm{~N} \mathrm{hm}^{-2}$, $135 \mathrm{~kg} \mathrm{P}_{2} \mathrm{O}_{5} \mathrm{hm}^{-2}$ and $150 \mathrm{~kg} \mathrm{~K}_{2} \mathrm{O} \mathrm{hm}^{-2}$. Half of the $\mathrm{N}$ and $\mathrm{K}$ were applied as a basal dressing and the remaining nutrients by topdressing in two applications. Urea, calcium superphosphate and potassium chloride were used as the sources of fertilizer $\mathrm{N}, \mathrm{P}$ and $\mathrm{K}$, respectively.

\subsection{Soil sampling and assay}

The original soil was sampled from the upper layer (0-20 $\mathrm{cm}$ ) in the field before the trial began. After both sudangrass and ryegrass were harvested in the final year of the study from 2008 to 2009, fresh soil samples were also collected from the upper layer $(0-20 \mathrm{~cm})$ in each plot. The samples were carefully passed through a 2-mm sieve for the analysis of soil microbial community activity, biomass and enzymes. To determine SOM and total $\mathrm{N}$, the soil samples were air-dried and sieved through a $0.149-\mathrm{mm}$ mesh.

Microbial community activity was analyzed by developing community physiological profiles using Biolog assays [20,21]. Briefly, $10 \mathrm{~g}$ of sieved soil was extracted in $100 \mathrm{~mL}$ of sterile saline solution $(0.85 \%, \mathrm{~m} / \mathrm{v})$ with $5 \mathrm{~g}$ glass beads on a rotary shaker at $200 \mathrm{r} \mathrm{min}^{-1}$ for $30 \mathrm{~min}$ at $25^{\circ} \mathrm{C}$. Suspensions were diluted 100-fold with sterile water and $150 \mu \mathrm{L}$ of the dilution was added to each well of a Biolog Eco-plate ${ }^{\mathrm{TM}}$. The plates were scanned at $590 \mathrm{~nm}$ at $24 \mathrm{~h}$ intervals for $7 \mathrm{~d}$, using an automated Biolog micro-station (Biolog, Hayward, CA, USA).

MBC and MBN were measured by the fumigation-extraction method [22]. Soil sucrase and urease were measured by the method reported by Guan [23]. SOM was determined by the oxidation method using $\mathrm{K}_{2} \mathrm{Cr}_{2} \mathrm{O}_{7}$ and concentrated sulfuric acid at $170-180^{\circ} \mathrm{C}$, and total $\mathrm{N}$ by the regular Kjeldhal method [24].

\subsection{Data analysis}

The average well color development (AWCD) in the Biolog Eco-plate was calculated according to Garland [20], and Biolog data were interpreted by principal component analysis (PCA). The AWCD of each plate was calculated as fol- 
lows:

$$
\mathrm{AWCD}=\Sigma(C-R) / 31,
$$

where $C$ is the average color developed in the control cell and $R$ is the value for an experimental cell.

Soil microbial community activity, MBC and MBN, enzymes, organic matter and total $\mathrm{N}$ were analyzed by ANOVA using the SPSS13.0 software package for Windows and the least significant difference was used to compare the treatments at a 0.05 probability.

\section{Results}

\subsection{Soil microbial community activity}

AWCD was used as an indicator of microbial community activity in the soil [25]. AWCD increased gradually in all treatments with increasing incubation time after the sudangrass trial in 2008 (Figure 1A). Fertilization regimes had a significant negative effect on AWCD, with AWCD values in the $\mathrm{N}$ addition treatments (NK, NP and NPK) being significantly lower than those in the $\mathrm{CK}$ and $\mathrm{PK}$ treatments $(P<0.05)$. After the planting of ryegrass in 2009 , the total AWCD in all treatments also increased gradually with increasing incubation time in the soil (Figure 1B). AWCD
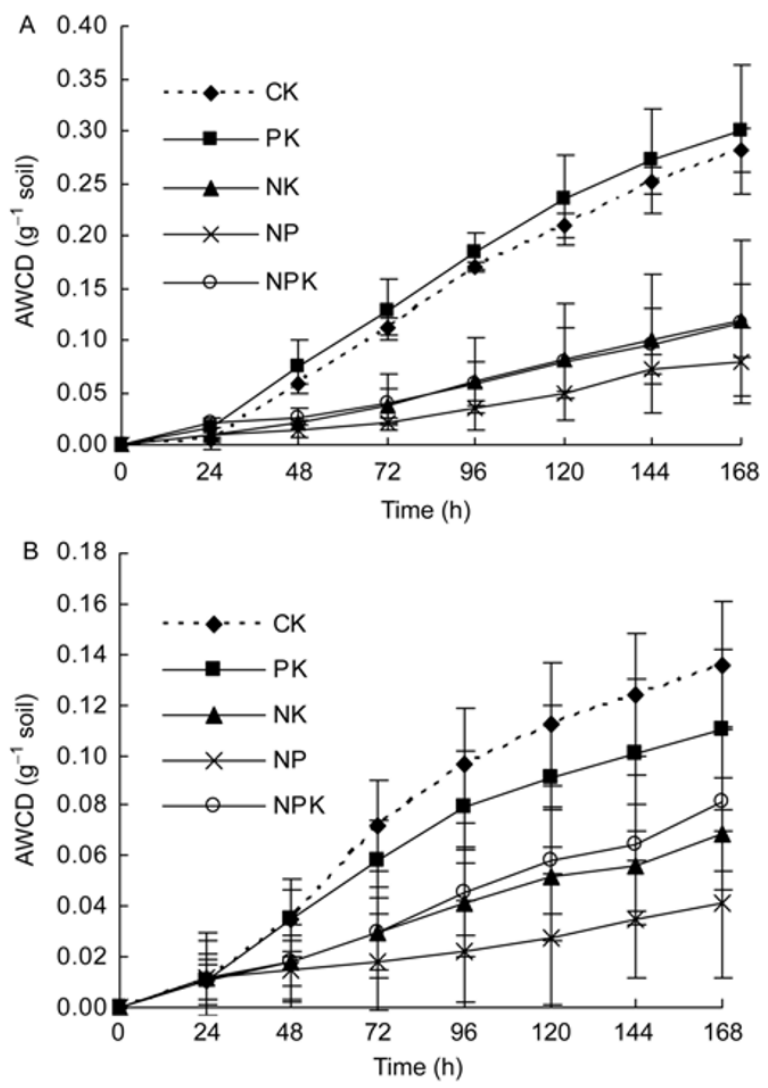

Figure 1 Soil microbial functional diversity in the sudangrass and ryegrass rotation system. A, Soil after the sudangrass trial. B, Soil after the ryegrass trial. Vertical lines indicate the standard error of all treatments. values in the $\mathrm{N}$ addition treatments (NK, NP and NPK) were also significantly lower than those in the CK and PK treatments $(P<0.05)$. Total AWCD values were highest in the CK treatment and lowest in the NP treatment.

The PCA of the absorbance of the 31 carbon sources in the Biolog Eco-plates is shown in Figure 2. The results show that the NPK and NP treatments were different from the $\mathrm{CK}, \mathrm{PK}$ and $\mathrm{NK}$ treatments after the sudangrass trial (Figure 2A), and that there were similar substrate categories between the CK and PK treatments. Exactly 36.9\% and $11.2 \%$ of the total data variability is explained by the first (PC1) and second (PC2) principal components, respectively. PCA on microbial community activity after the ryegrass trial based on carbon source usage in all treatments is shown in Figure 2B. The NP treatment was different from the other treatments, and there was also similar carbon source utilization in the $\mathrm{CK}$ and PK treatments. The variability explained by the first and second PCA components was $26.5 \%$ and $14.2 \%$, respectively.

\subsection{MBC and MBN}

Soil MBC in the sudangrass and ryegrass rotation system is shown in Figure $3 \mathrm{~A}$ and B. Fertilizer application significantly influenced soil MBC. After the sudangrass and ryegrass trial, MBC in the NK, NP and NPK treatments in-
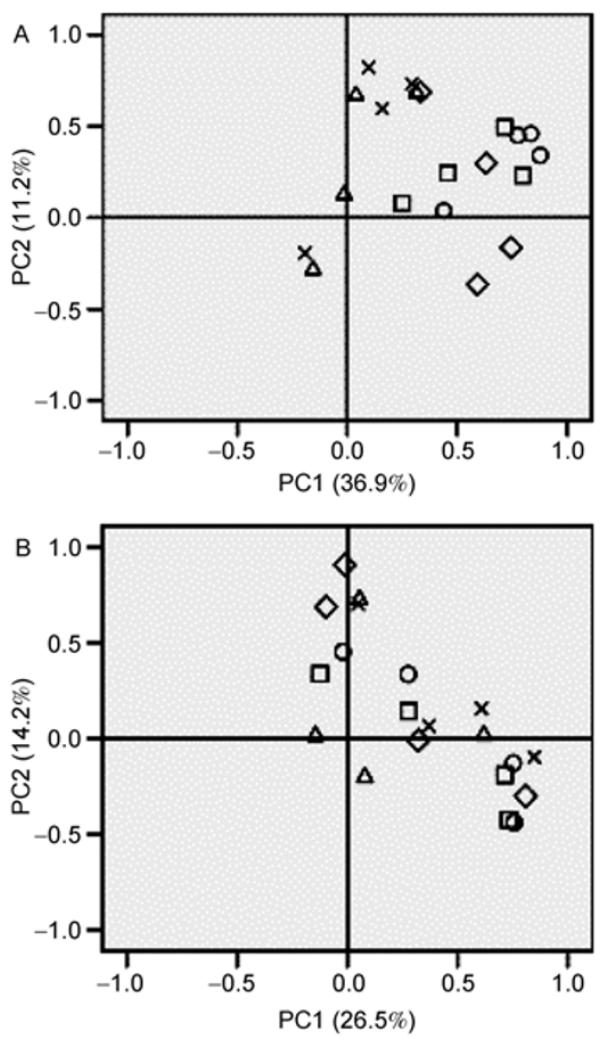

Figure 2 Principal component analysis on microbial functional diversity in all treatments. $72 \mathrm{~h}$ BIOLOG data adjusted for average well color development (AWCD). A, AWCD in the sudangrass trial. B, AWCD in the ryegrass trial. $\bigcirc, \mathrm{CK} ; \square, \mathrm{PK} ; \diamond, \mathrm{NK} ; \triangle, \mathrm{NP} ; \times, \mathrm{NPK}$ 

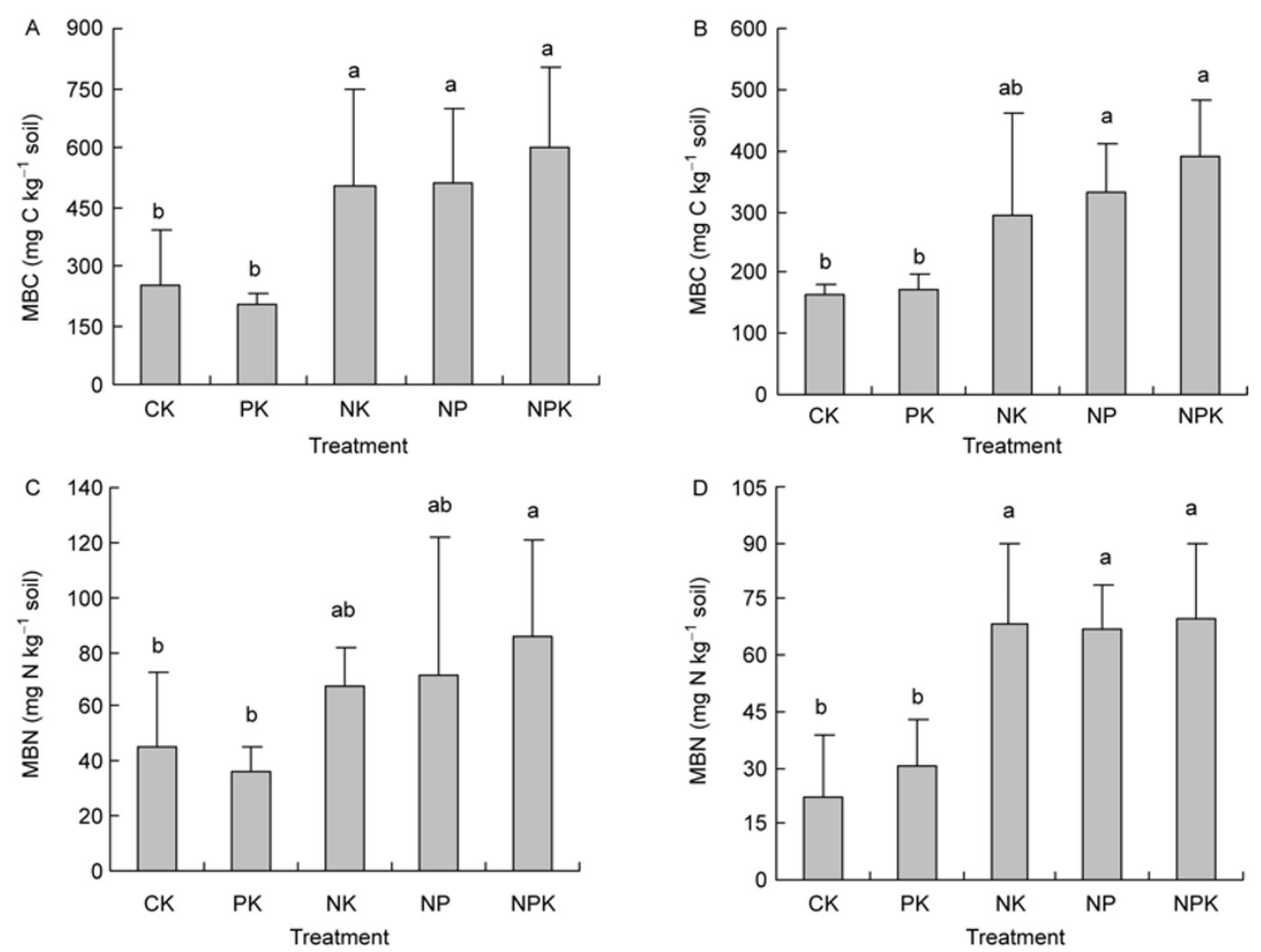

Figure 3 Soil MBC and MBN in the sudangrass and ryegrass rotation system. A, MBC in soil after the sudangrass trial. B, MBC in soil after the ryegrass trial. C, MBN in soil after the sudangrass trial. D, MBN in soil after the ryegrass trial. Small letter differences mean significant differences at $P<0.05$.

creased significantly compared with that in the CK treatment $(P<0.05)$, with the NPK treatment the highest followed by the NP and NK treatments, while MBC in the PK treatment was similar to that in the $\mathrm{CK}$ treatment.

Fertilization regimes also influenced $\mathrm{MBN}$ in soil after the sudangrass and ryegrass trial (Figure $3 \mathrm{C}$ and D). MBN in the NPK treatment was highest after the sudangrass and ryegrass trial followed by the NP and NK treatments. MBN in the NK, NP and NPK treatments was higher than that in the $\mathrm{CK}$ and $\mathrm{PK}$ treatments, while MBN in the PK treatment was similar to that in the $\mathrm{CK}$ treatment.

The MBC/MBN ratios in the $\mathrm{CK}$ and $\mathrm{PK}$ treatments were 5.4-5.5 after the sudangrass trial, and were lower than those in the NP, NK and NPK treatments (7.0-7.5). After the ryegrass trial, the $\mathrm{MBC} / \mathrm{MBN}$ ratio in the $\mathrm{CK}$ treatment was 7.3, which was higher than those in the other treatments (4.3-5.7).

\subsection{Soil enzymes}

Soil sucrase activities in the NP and NPK treatments were significantly higher than those in the CK, PK and NK treatments after the sudangrass trial (Figure 4A). Soil sucrase activity in the NPK treatment was highest with 63.0 mg glucose $\mathrm{g}^{-1}$ soil $24 \mathrm{~h}$, and was lowest in the CK treatment with $25.1 \mathrm{mg}$ glucose $\mathrm{g}^{-1}$ soil $24 \mathrm{~h}$. After the ryegrass trial (Figure 4B), soil sucrase activity in the NPK treatment was highest with $34.4 \mathrm{mg}$ glucose $\mathrm{g}^{-1}$ soil $24 \mathrm{~h}$, while the PK treatment was the lowest with $24.8 \mathrm{mg}$ glucose $\mathrm{g}^{-1}$ soil $24 \mathrm{~h}$.

Soil urease activity in the NPK treatment with $125.4 \mu \mathrm{g}$ $\mathrm{NH}_{4}-\mathrm{N} \mathrm{g}^{-1}$ soil $24 \mathrm{~h}$ was highest after the sudangrass trial (Figure 4C), although soil urease activities in all treatments were not significantly different $(P<0.05)$. After the ryegrass trial (Figure 4D), soil urease activities in the NK, NP and NPK treatments were significantly higher than that in the CK treatment, while the PK treatment had the lowest soil urease activity with $53.8 \mu \mathrm{g} \mathrm{NH}_{4}-\mathrm{N} \mathrm{g}^{-1}$ soil $24 \mathrm{~h}$.

\subsection{SOM and total N}

Fertilization regimes increased SOM in the sudangrass and ryegrass rotation system (Table 1 ). The original content of SOM was $18.50 \mathrm{~g} \mathrm{~kg}^{-1}$, and after the sudangrass and ryegrass trial, SOM in the NPK treatment was highest with $25.66 \mathrm{~g} \mathrm{~kg}^{-1}$ and $24.01 \mathrm{~g} \mathrm{~kg}^{-1}$, respectively. SOM in the CK treatment was the lowest but it also increased compared with that in the original soil.

$\mathrm{N}$ application increased total $\mathrm{N}$ in soil in the sudangrass and ryegrass rotation system (Table 1 ). Compared with the original soil concentration (1.05 $\mathrm{g} \mathrm{kg}^{-1}$ total $\left.\mathrm{N}\right)$, total $\mathrm{N}$ in the NK, NP and NPK treatments increased significantly, 

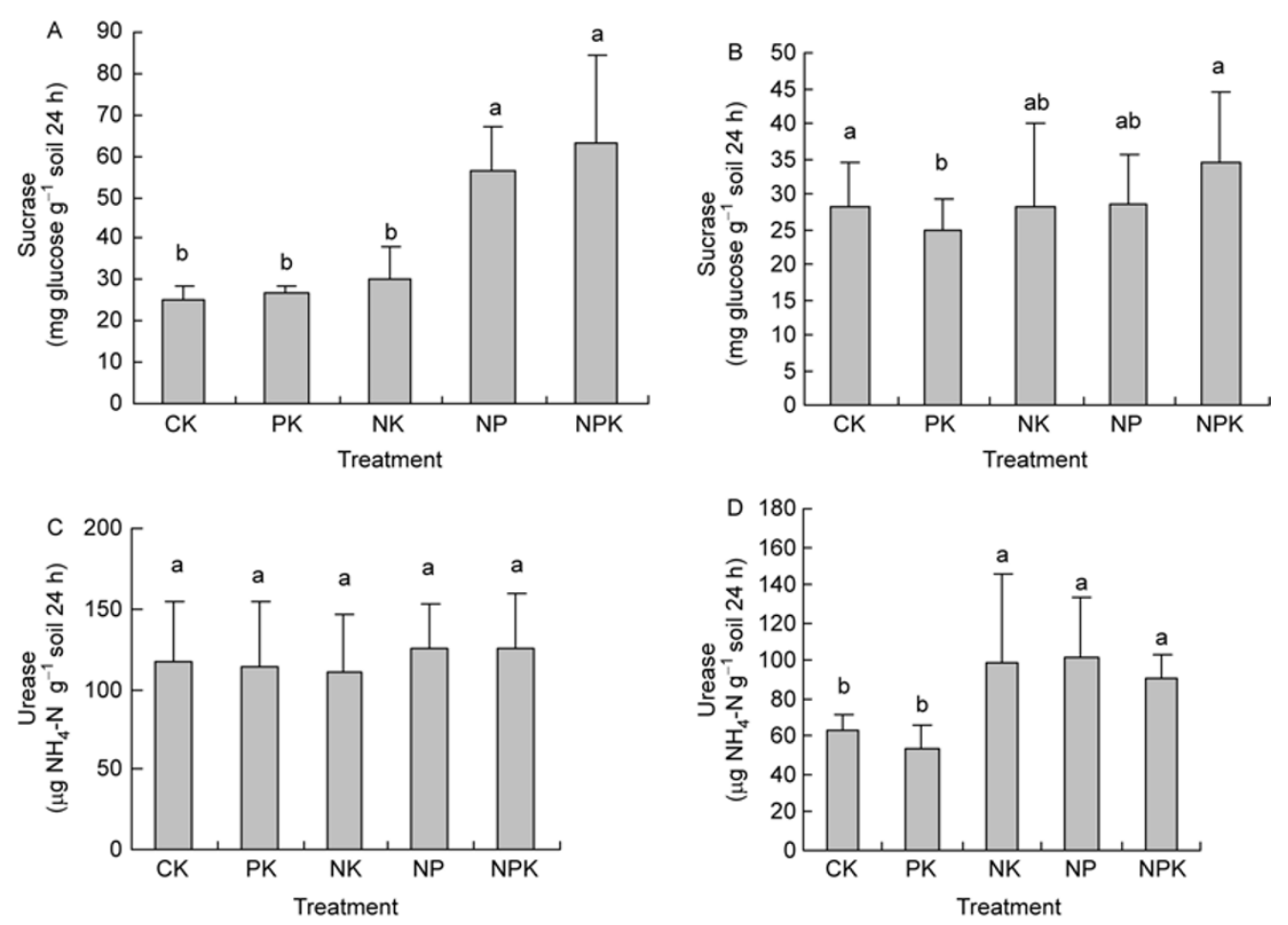

Figure 4 Soil sucrase and urease activities in the sudangrass and ryegrass rotation system. A, Sucrase in soil after the sudangrass trial. B, Sucrase in soil after the ryegrass trial. C, Urease in soil after the sudangrass trial. D, Urease in soil after the ryegrass trial. Small letter differences mean significant differences at $P<0.05$.

Table 1 Organic matter and total $\mathrm{N}$ in soil after the sudangrass and ryegrass trials in the rotation system ${ }^{\text {a) }}$

\begin{tabular}{cccccc}
\hline \multirow{2}{*}{ Treatment } & \multicolumn{2}{c}{ Organic matter $\left(\mathrm{g} \mathrm{kg}^{-1}\right)$} & & \multicolumn{2}{c}{ Total N $\left(\mathrm{g} \mathrm{kg}^{-1}\right)$} \\
\cline { 2 - 3 } \cline { 5 - 6 } & Sudangrass & Ryegrass & & Sudangrass & Ryegrass \\
\hline CK & $19.20 \pm 3.05 \mathrm{~b}$ & $20.95 \pm 1.60 \mathrm{a}$ & & $1.09 \pm 0.48 \mathrm{~b}$ & $1.11 \pm 0.11 \mathrm{~b}$ \\
PK & $21.33 \pm 2.36 \mathrm{~b}$ & $21.78 \pm 3.02 \mathrm{a}$ & & $1.07 \pm 0.19 \mathrm{~b}$ & $1.05 \pm 0.13 \mathrm{~b}$ \\
NK & $21.02 \pm 3.90 \mathrm{~b}$ & $22.79 \pm 2.04 \mathrm{a}$ & & $1.51 \pm 0.16 \mathrm{a}$ & $1.44 \pm 0.10 \mathrm{a}$ \\
NP & $22.31 \pm 2.41 \mathrm{ab}$ & $22.65 \pm 4.87 \mathrm{a}$ & & $1.19 \pm 0.51 \mathrm{~b}$ & $1.33 \pm 0.18 \mathrm{a}$ \\
NPK & $25.66 \pm 1.21 \mathrm{a}$ & $24.01 \pm 2.12 \mathrm{a}$ & & $1.36 \pm 0.26 \mathrm{ab}$ & $1.35 \pm 0.22 \mathrm{a}$ \\
\hline
\end{tabular}

a) Means with different letters in the same column differed significantly $(P<0.05)$.

while the CK and PK treatments had total $\mathrm{N}$ contents similar to that in the original soil.

\subsection{Correlation of MBC, MBN, sucrase, urease, SOM and total $\mathbf{N}$}

Correlations between MBC, MBN, sucrase, urease, SOM and total $\mathrm{N}$ are shown in Table 2. After the sudangrass trial, there were significant positive correlations between MBC and MBN $(r=+0.989)$, and sucrase and urease $(r=+0.882)$. After the ryegrass trial, there were significant positive correlations between MBC and MBN ( $r=+0.945)$, SOM and MBC $(r=+0.944)$, SOM and MBN $(r=+0.891)$, TN and MBN ( $r=+0.940)$, TN and urease $(r=+0.958)$, and MBN and urease $(r=+0.934)$. The results indicate that the soil microbial biomass and soil enzymes have an important role in the utilization of SOM and total $\mathrm{N}$ in sudangrass and ryegrass rotation systems.

\section{Discussion}

\subsection{Soil microbial community activity and microbial biomass}

Microbial community activity depends on many factors such as fertilizers and crop types [26,27]. C source utilization patterns reflect the catabolic potential of a microbial community $[28,29]$. Biolog plates have been increasingly used to characterize microbial community activity with overall color development in Biolog plates expressed as AWCD [25]. In this study, the AWCD in the $\mathrm{N}$ addition treatments (NK, NP and NPK) significantly decreased compared with those in the CK and PK treatments in the sudangrass and ryegrass rotation system (Figure 1). C source utilization explained by the first and second PCA components was different from the $\mathrm{CK}$ and PK treatments, suggesting that $\mathrm{N}$ application reduced the $\mathrm{C}$ source utilization of the soil microbial communities. Fertilizer $\mathrm{N}$ probably either directly or indirectly reduced microbial community activity in the soils. Similar results have been reported by Sarathchandra et al. [29] and Benizri et al. [30]. The biodiversity and activity of the soil microbial community is important to maintain soil ecosystem function [31]. Meas- 
Table 2 Correlation matrices between MBC, MBN, sucrase, urease, SOM and TN in the rotation system ${ }^{\text {a) }}$

\begin{tabular}{|c|c|c|c|c|c|c|c|c|c|c|}
\hline \multirow{2}{*}{ Variables } & \multicolumn{5}{|c|}{ Sudangrass trial } & \multicolumn{5}{|c|}{ Ryegrass trial } \\
\hline & $\mathrm{MBC}$ & MBN & Sucrase & Urease & SOM & $\mathrm{MBC}$ & MBN & Sucrase & Urease & SOM \\
\hline $\mathrm{MBN}$ & $0.989^{*}$ & & & & & $0.945^{*}$ & & & & \\
\hline Sucrase & 0.811 & 0.858 & & & & 0.797 & 0.602 & & & \\
\hline Urease & 0.503 & 0.602 & $0.882^{*}$ & & & 0.855 & $0.934^{*}$ & 0.530 & & \\
\hline SOM & 0.733 & 0.769 & 0.872 & 0.661 & & $0.944^{*}$ & $0.891^{*}$ & 0.767 & 0.697 & \\
\hline $\mathrm{TN}$ & 0.770 & 0.702 & 0.271 & -0.144 & 0.377 & 0.842 & $0.940^{*}$ & 0.576 & $0.958^{*}$ & 0.755 \\
\hline
\end{tabular}

a) *, Pearson correlation is significant at the 0.05 level.

urement of the activities of microbial communities contributing to soil processes has the potential to provide particularly rapid and sensitive means of characterizing changes in soil quality [32]. Enhanced soil microbial activity was associated with high soil available $\mathrm{N}$ for plants [33], and soil microbial activity was likely to be greatest in row areas with a higher $\mathrm{C}$ input [34].

Soil microbial biomass is involved in nutrient cycling and transformation processes, which are closely related to soil fertility $[35,36]$. In the sudangrass and ryegrass rotation system, MBC and MBN in the NPK treatments were higher than those in the other treatments, indicating that the combination of N, P and K fertilizers could improve soil microbial biomass. Soil microbial biomass was positively associated with SOM in this rotation system (Table 2). Increased soil microbial biomass because of fertilization was a result of better crop growth and larger amounts of root residue left in the soil, which positively influenced microbial processes and development $[37,38]$.

In this study, the most striking result observed was that the Biolog data showed significantly reduced microbial community activity after $\mathrm{N}$ fertilization, while $\mathrm{MBC}$ and MBN in the soil showed significant stimulation. Biolog plates have been used to evaluate microbial community activity, and direct sample incubation in Biolog Ecoplates may generate metabolic response patterns which were suitable for the rapid classification of heterotrophic microbial communities [4,25]. Biolog Eco-plates are tailored to ecological applications and comprise three replicate sets of 31 environmentally applicable substrates, at least nine of which are constituents of plant root exudates [39]. Although microbial community activities in our study were lower after $\mathrm{N}$ fertilization, maybe there were additional factors, such as other root residues, which may have affected the microbial community activities indicated in the incubation environment. Furthermore, the 31 carbon substrates assays in the Biolog Eco-plates certainly present functional diversity of microbial community, but do not reflect absolute microbial community activity which will be different from that of the soil microbial biomass. Soil microbial biomass is an important pool of plant nutrients and is highly correlated with SOM [40]. In our study, microbial biomass also increased along with increasing content of organic matter after $\mathrm{N}$ fertilization.

\subsection{Soil enzymes}

Soil enzymes have an important role in soil characteristics and are also involved in nutrient cycling processes. Enzyme activities and soil microbial biomass are closely related because transformations of the important organic elements occur through microorganisms $[15,35,36]$. Similar to microbial biomass in the sudangrass and ryegrass rotation system, sucrase and urease in the NPK treatments were higher than those in the other treatments, indicating that the combination of N, P and K fertilizers also improved soil enzyme activities. Some studies have shown that the application of chemical fertilizers increases soil enzyme activities [40,41], which were positively associated with SOM in this rotation system (Table 2). Soil enzymes can catalyze the transformation of SOM $[35,42,43]$. Increasing enzyme activities in the soil indicate improved soil fertility [40].

\subsection{SOM and total N}

Both SOM and total $\mathrm{N}$ are critical components of soil fertility and the level of organic matter and total $\mathrm{N}$ are influenced by fertilization regimes and crop rotation [44]. In the sudangrass and ryegrass rotation system, the level of SOM due to the combination of N, P and $\mathrm{K}$ fertilizers was higher than those in the other treatments. The level of SOM is considered to be a function of the net input of organic residues $[45,46]$. Fertilization regimes presumably affect the content of SOM by increasing aboveground and belowground production of crop residue biomass that would influence the SOM pool $[17,47]$. SOM in the CK treatment increased by $13.2 \%$ in the rotation system compared with that in the original soil, and it is likely that root residues added to the soil in this rotation system resulted in the increased organic $\mathrm{C}$ pools. Total $\mathrm{N}$ in soil from $\mathrm{N}$ application also increased by $26.7 \%-37.1 \%$, while total $\mathrm{N}$ in the $\mathrm{CK}$ and $\mathrm{PK}$ treatments was similar to that in the original soil. However, $\mathrm{N}$ uptake in the CK and PK treatments occurred due to grass growth every year. Therefore, it was assumed that the crop residues and rainfall maintained the $\mathrm{N}$ balance in the rotation system. Similar results have already shown that SOM and total $\mathrm{N}$ increase with increasing $\mathrm{N}$ applied in continuous wheat under conventional tillage [48]. The benefits of bal- 
anced fertilization in maintaining SOM levels have been increasingly emphasized, and the increasing level of SOM due to proper fertilization regimes also means an improvement in soil fertility $[42,49,50]$.

\section{Conclusion}

In a sudangrass and ryegrass rotation system, microbial community activity was changed following application of $\mathrm{N}$, $\mathrm{P}$ and $\mathrm{K}$ fertilizer combinations. Soil microbial biomass, enzyme activities and soil nutrients all increased, improving soil fertility. For sustainable agricultural production in intensive cropping systems, proper fertilization regimes will sustain soil fertility for agricultural production.

This work was supported by the International Plant Nutrition Institute (Grant No. Hubei-22), the National Key Technologies R\&D Program of China (Grant No. 2008BADA4B08) and the National Department Public Benefit Research Foundation (Grant No. 200803029). The authors gratefully acknowledge Dr. Wang LiJun for editing this manuscript.

1 Hossain M, Singh V P. Fertilizer use in Asian agriculture: Implications for sustaining food security and the environment. Nutr Cycl Agroecosys, 2000, 57: 155-169

2 Yang H, Li X B. Cultivated land and food supply in China. Land Use Policy, 2000, 17: 73-88

3 Leita L, Nobili M D, Mondini C, et al. Influence of inorganic and organic fertilization on soil microbial biomass, metabolic quotient and heavy metal bioavailability. Biol Fertil Soils, 1999, 28: 371-376

4 Katayama A, Hu H Y, Nozawa M, et al. Long-term changes in microbial community structure in soils subjected to different fertilizing practices revealed by quinine profile analysis. Soil Sci Plant Nutr, 1998, 44: 559-570

5 Wang L, Liu B, Zhou Z M. Research progress in genomics of environmental and industrial microorganisms (in Chinese). Sci China Ser C-Life Sci, 2009, 52: 64-73

6 Mader P, Fliessbach A, Dubois D, et al. Soil fertility and biodiversity in organic farming. Science, 2000, 296: 1694-1698

7 Schloter M, Dilly O, Munch J C. Indicators for evaluating soil quality. Agri Ecosys Environ, 2003, 98: 255-262

8 Fox C A, MacDonald K B. Challenges related to soil biodiversity research in agroecosystems-issues within the context of scale of observation. Can J Soil Sci, 2003, 83: 231-244

9 Wei D, Yang Q, Zhang J Z, et al. Bacterial community structure and diversity in a black soil as affected by long-term fertilization. Pedosphere, 2008, 18: 582-592

10 Bardgett R D, Shine A. Linkages between litter diversity, soil microbial biomass and ecosystem function in temperate grasslands. Soil Biol Biochem, 1999, 31: 317-321

11 Wardle D A, Bonner K I, Barker G M, et al. Plant removals in perennial grassland: Vegetation dynamics, decomposers, soil biodiversity, and ecosystem properties. Ecol monographs, 1999, 69: 535-568

12 Bohme L, Langer U, Bohme F. Microbial biomass, enzyme activities and microbial community structure in two European long-term field experiments. Agri Ecosyst Environ, 2005, 109: 141-152

13 Kandeler E, Eder G. Effect of cattle slurry in grassland on microbial biomass and on activities of various enzymes. Biol fert Soils, 1993, 16: 249-254

14 Aon M A, Cabello M N, Sarena D E, et al. Spatio-temporal patterns of soil microbial and enzymatic activities in an agricultural soil. Appl Soil Ecol, 2001, 18: 239-254

15 Ajwa $\mathrm{H}$ A, Dell C J, Rice C W. Changes in enzyme activities and microbial biomass of tallgrass prairie soil as related to burning and nitrogen fertilization. Soil Biol Biochem, 1999, 31: 769-777

16 Salinas-Garcia J R, Hons F M, Matocha J E. Long-term effects of tillage and fertilization on soil organic matter dynamics. Soil Sci So Am J, 1997, 61: 152-159

17 Halvorson A D, Reule C A, Follett R F. Nitrogen fertilization effects on soil carbon and nitrogen in a dryland cropping systems. Soil Sci So Am J, 1999, 63: 912-917

18 Lu J W, Chen F, Liang Y G, et al. Effect of phosphorus and potassium fertilizer on economic benefit and yield of forage grass (in Chinese). Reservior Fisheries, 2003, 23: 58-59

19 Lu J W, Li X K, Liang Y G, et al. Effect of balance fertilization on growth and yield of Ryegrass (in Chinese). Reservior Fisheries, 2004, 24: $20-22$

20 Garland J L. Analytical approaches to the characterization of samples of microbial communities using patterns of potential C source utilization. Soil Biol Biochem, 1996, 28: 213-221

21 Staddon W J, Duchesne L C, Trevors J T. Microbial diversity and community structure of postdisturbance forest soils as determined by sole-carbon-source utilization patterns. Micro Ecol, 1997, 34: $125-130$

22 Wu J S, Lin Q M, Huang Q Y, et al. Application and the Determination Method of Soil Microbial Biomass (in Chinese). Beijing: Meteorological Press, 2006

23 Guan S Y. Soil Enzymes and Their Research Methodology (in Chinese). Beijing: Agriculture Press, 1986

24 Bao S D. Soil and Agricultural Chemistry Analysis (in Chinese). Bejing: China Agricultural Press, 2000

25 Garland J L, Mills A L. Classification and characterization of heterotrophic microbial communities on the basis of patterns of community-level sole-carbon-source utilization. Appl Environ Microbiol, 1991, 57: 2351-2359

26 Kong W D, Zhu Y G, Fu B J, et al. Effect of long-term application of chemical fertilizers on microbial biomass and functional diversity of a black soil. Pedosphere, 2008, 18: 801-808

27 Garcia-Ruiz R, Ochoa V, Vinegla B, et al. Soil enzymes, nematode community and selected physico-chemical properties as soil quality indicators in organic and conventional olive oil farming: Influence of seasonality and site features. Appl Soil Ecol, 2009, 41: 305-314

28 Degens B P, Schipper L A, Sparling G P, et al. Decreases in organic $\mathrm{C}$ reserves in soils can reduce the catabolic diversity of soil microbial communities. Soil Biol Biochem, 2000, 32: 189-196

29 Sarathchandra S U, Ghani A, Yeates G W, et al. Effect of nitrogen and phosphate fertilizers on microbial and nematode diversity in pasture soils. Soil Biol Biochem, 2001, 33: 953-964

30 Benizri E, Amiaud B. Relationship between plants and soil microbial communities in fertilized grasslands. Soil Biol Biochem, 2005, 37: 2055-2064

31 Nsabimana D, Haynes R J, Wallis F M. Size, activity and catabolic diversity of the soil microbial biomass as affected by land use. Appl Soil Ecol, 2004, 26: 81-92

32 Bending G D, Turner M K, Rayns F, et al. Microbial and biochemical soil quality indicators and their potential for differentiating areas under contrasting agricultural management regimes. Soil Biol Biochem, 2004, 36: 1785-1792

33 Tu C, Ristaino J B, Hu S. Soil microbial biomass and activity in organic tomato farming systems: Effects of organic inputs and straw mulching. Soil Biol Biochem, 2006, 38: 247-255

34 Dominy C S, Haynes R J. Influence of agricultural land management on organic matter content, microbial activity and aggregate stability in the profiles of two Oxisols. Biol Fert Soils, 2002, 36: 298-305

35 Sollins P, Homann P, Caldwell B A. Stabilization and destabilization of soil organic matter: Mechanisms and controls. Geoderma, 1996, 74: 64-105

36 Maharning A R, Mills A A S, Adl S M. Soil community changes during secondary succession to naturalized grasslands. Appl Soil Ecol, 2009, 41: 137-147

37 Kandeler E, Tscherko D, Spiegel H. Long-term monitoring of microbial biomass, $\mathrm{N}$ mineralization and enzyme activities of a Chernozem 
under different tillage management. Biol Fert Soils, 1999, 28: 343-351

38 Gu Y F, Zhang X P, Tu S H. Soil microbial biomass, crop yields, and bacterial community structure as affected by long-term fertilizer treatments under wheat-rice cropping. Eu J Soil Biol, 2009, 45: 239-246

39 Preston-Mafham J, Boddy L, Randerson P F. Analysis of microbial community functional diversity using sole-carbon-source ulitisation profiles-a critique. FEMS Microbiol Ecol, 2002, 42: 1-4

40 Yao H, He Z, Wilson M J, et al. Microbial biomass and community structure in a sequence of soils with increasing fertility and changing land use. Microb Ecol, 2000, 40: 223-237

41 Lundquist E J, Jackson L E, Scow K M. Changes in microbial biomass and community composition and soil carbon and nitrogen pools after incorporation of rye into three California agricultural soils. Soil Biol Biochem, 1999, 31: 221-236

42 Jiao X, Liang W, Chen L, et al. Effects of slow-release urea fertilizers on urease activity, microbial biomass, and nematode communities in an aquic brown soil. Sci China Ser C-Life Sci, 2005, 48: 26-32

43 Jonasson S, Michelsen A, Schmidt I K, et al. Microbial biomass C, N and $\mathrm{P}$ in two arctic soils and responses to addition of NPK fertilizer and sugar: Implications for plant nutrient uptake. Oecologia, 1996, 106: $507-515$
44 Fisk M C, Fahey T J. Microbial biomass and nitrogen cycling responses to fertilization and litter removal in young northern hardwood forests. Biogeochem, 2001, 53: 201-223

45 Chander K, Goyal S, Nandal D P, et al. Soil organic matter, microbial biomass and enzyme activities in a tropical agroforestry system. Biol Fert Soils, 1998, 27: 168-172

46 Gregorich E G, Ellert B H, Drury C F, et al. Fertilization effects on soil organic matter turnover and corn residue storage. Soil Sci So Am J, 1996, 60: 472-476

47 Fu S, Howard F. Plant species, atmospheric $\mathrm{CO}_{2}$ and soil $\mathrm{N}$ interactively or additively control C allocation within plant-soil systems (in Chinese). Sci China Ser C-Life Sci, 2006, 49: 603-612

48 Galantini J, Rosell R. Long-term fertilization effects on soil organic matter quality and dynamics under different production systems in semiarid Pampean soils. Soil Tillage Res, 2006, 87: 72-79

49 Raun W R, Johnson G V, Phioolips S B, et al. Effect of long-term N fertilization on soil organic $\mathrm{C}$ and total $\mathrm{N}$ in continuous wheat under conventional tillage in Oklahoma. Soil Tillage Res, 1998, 47: 323-330

50 Kanchikerimath M, Singh D. Soil organic matter and biological properties after 26 years of maize-wheat-cowpea cropping as affected by manure and fertilization in a Cambisol in semiarid region of India. Agri Ecosyst Environ, 2001, 86: 155-162

Open Access This article is distributed under the terms of the Creative Commons Attribution License which permits any use, distribution, and reproduction in any medium, provided the original author(s) and source are credited. 